\title{
EFFECTS OF RATIONS WITH VARIOUS BALANCES OF ENERGY AND PROTEIN ON PERFORMANCE AND CARCASS QUALITY OF MALE ALABIO DUCKS
}

\author{
Danang BIYATMOKO ${ }^{\circledR \otimes}$, Tintin ROSTINI², and Untung SANTOSO3 \\ ${ }^{1}$ Department of Animal Science, Lambung Mangkurat University, Indonesia \\ 2Department of Animal Science, Islamic University of Kalimantan, Banjarmasin, Indonesia \\ ${ }^{3}$ Department of Agroecotechnology, Lambung Mangkurat University, Indonesia \\ Email: danangbiyatmoko@ulm.ac.id; (D) ORCiD: 0000-0002-4377-3105 \\ supporting Information
}

ABSTRACT: For suitable nutrition according to the requirements of Alabio male ducks, it is necessary to balance metabolic energy and protein. The purpose of the study was to analyze the effect of the energy and protein balance (E/CP) on the growth achievement and carcass quality of Alabio male duck. The feeding trial study was conducted in a poultry house for six weeks. The research method used a completely randomized design (CRD) with factorial pattern where is the first factor being metabolic energy+y level (E) consisting of E1: $2800 \mathrm{kcal} / \mathrm{kg} \mathrm{ME}$, E2: $2900 \mathrm{kcal} / \mathrm{kg} \mathrm{ME}$, E3: $3000 \mathrm{kcal} / \mathrm{kg} \mathrm{ME}$, while the second factor was crude protein level (CP) consisting of P1: 15\% CP, P2: 16\% CP, P3: 17\% CP, with three replications, where each replication consisted of five ducks with a total of 135 male Alabio ducks. The observed variables were final body weight (BW), body weight gain (BWG), feed intake (FI), feed conversion ratio (FCR), carcass percentage, carcass fat, and abdominal fat. The data obtained have been analyzed by analysis of variance (ANOVA) method. The results showed that there was an interaction between $(E)$ and $(C P)$, where the best results were obtained in the combination of E2P3 treatment with an E/CP ratio of 17.1 (ME $2900 \mathrm{kcal} / \mathrm{kg}, 17 \% \mathrm{CP}$ ), including BW at $1185.0 \mathrm{~g} / \mathrm{bird}, \mathrm{BWG}$ at $1134.0 \mathrm{~g} / \mathrm{bird}, \mathrm{Fl}$ at $3563.21 \mathrm{~g} / \mathrm{bird}$, and FCR at 3.14 and the lowest carcass quality with the highest carcass percentage reaching $67.33 \%$, and the lowest carcass fat and abdominal fat were $0.37 \%$ and $0.75 \%$, respectively. It was concluded that the effect of E/P ration at ratio of 17.1 gives the best result on the performance of male Alabio ducks including the achievement of BW, BWG, FI and FCR, and carcass quality through the achievement of increasing carcass percentage, decreasing carcass fat and fat abdominals.

Keywords: Alabio duck, Carcass Quality, Crude protein, Performance, Ration.

\section{INTRODUCTION}

The main obstacle for the Alabio broiler poultry industry for the purpose of producing meat is the price of feed which is still relatively expensive and the profits are not yet feasible (Biyatmoko, 2016; Rostini et al., 2021). In addition to the price of feed, another obstacle is the supply of quality feed (Biyatmoko et al., 2021). A study is needed considering that the level of consumption of ducks is strongly influenced by the nutritional content of the ration, and the energy-protein balance (E/CP) of the duck ration. Tanwiriah (2011) stated that a suitable E/CP balance for growth and income over feed cost of local male local ducks is 17.33 with an energy of $2600 / \mathrm{kg}$ with a protein of $15 \%$, while Zurmiati et al. (2017) got the highest growth of Pitalah ducks of $1,037.66 \mathrm{~g} / \mathrm{bird}$ and the best FCR of 4.62 at the E/CP balance of $16(2700 \mathrm{kcal} / \mathrm{kg}$ energy and $17 \% \mathrm{CP}$ ) which can reduce the energy requirement of the ration by $3.5 \%$ and protein of $17 \%$. Meanwhile Wahyuni et al. (2016) reported that the increase in weight and the highest percentage of carcass and the lowest percentage of abdominal fat in Cihateup male ducks and Rambon male ducks eight weeks old was produced by feeding with an E/CP balance of 20 with an energy content of $2700 \mathrm{kcal} / \mathrm{kg}$ and protein of $13.5 \%$. Zeng et al. (2015) reported that the best body weight gain and feed conversion ratio were obtained when the ducks were fed a high energy diet of $2700 \mathrm{kcal} / \mathrm{kg}(13.75 \mathrm{MJ} / \mathrm{kg}$ ) and high protein (19\%). These results provide a framework for further modeling of amino acids and corresponding energy inputs and outputs of growth performance and carcass components. Sritiawthai et al. (2013) obtained a ration with $18 \%$ protein and $11.29 \mathrm{MJ} \mathrm{ME} / \mathrm{kg}$ calories was the right balance to increase feed efficiency and achieve the best body weight and feed conversion (FCR) from 1 to 14 days of age in Cherry Valley ducks.

For carcass quality, the significant interaction between protein and energy shows the importance of E/CP balanced to achieve optimal carcass performance and carcass characteristics in broilers. Fan et al. (2008) observed an increase in carcass fat with increasing dietary energy levels, and this fat is usually considered a waste product when 6-week Pekin ducks are further processed, indicating an economic loss for poultry producers. However, Zeng et al. (2015) reported that there is an interaction effect of feed energy and protein or amino acid density on the performance and carcass properties of Pekin ducks from 14 to 35 days of age. In addition, the optimal processing age of broiler ducks with various nutrients to provide guidelines in optimizing ration costs, livestock performance, and carcass yields. Murawska (2012) observed 
that lean meat weight, the most valuable component of ducks, increased by the end of rearing from $35.8 \mathrm{~g}$ in one weekold birds to $1047 \mathrm{~g}$ at eight weeks, and breast muscle weight increased $188 \mathrm{~g}$ up over eight weeks. A significant increase in skin weight and subcutaneous fat was observed until the $7^{\text {th }}$ week. Research has shown that carcass characteristics can be changed through manipulation of the protein balance or ration energy in broilers (Niu et al., 2009). Suryana et al. (2016) expressed that efforts to increase the growth of male ducks and increase the percentage of carcass quality must consider the amount and quality of feed that is in accordance with the needs of life and meat production.

Based on the described problems, the purpose of the study was to analyze the effect of the energy and protein balance $(E / C P)$ of the ration on the growth achievement, carcass fat and abdominal fat of male Alabio duck

\section{MATERIALS AND METHODS}

\section{Ethical approval}

All procedures of experiment was approved by Animal Ethics and Welfare of the Research Institute of Lambung Mangkurat University Banjarmasin. Ethical clearance number LPPM.10.08.21

\section{Experimental livestock}

This research was conducted in a poultry cage laboratory for six weeks. Treatment using ducklings (dod) from male Alabio ducks. The research method used a completely randomized design with factorial pattern where is the first factor was metabolic energy level (E) consisting of E1: ME $2800 \mathrm{kcal} / \mathrm{kg}$, E2: ME $2900 \mathrm{kcal} / \mathrm{kg}$, E3: ME $3000 \mathrm{kcal} / \mathrm{kg}$, while the second factor was crude protein level (CP) consisting of P1: 15\% CP, P2: 16\% CP, P3: 17\% CP, with 3 replications, where each replication consisted of five ducks with a total of 135 male Alabio ducks.

\section{Feed ingredients and treatment rations}

The rations is made with a formula consisting of fish meal, Azolla meal, pollard, rice bran, yellow corn, and vegetable oil. The treatment ration was consisted of nine treatment combinations of treatment given from one day old ducks to get the optimal balance of giving E/CP rations for 6 weeks of rearing male Alabio ducks were as follows:

E1P1: $2800 \mathrm{kcal} / \mathrm{kg} \mathrm{ME}$ and $15 \% \mathrm{CP}$

E2P1: $2900 \mathrm{kcal} / \mathrm{kg} \mathrm{ME}$ and $15 \% \mathrm{CP}$

E3P1: $3000 \mathrm{kcal} / \mathrm{kg} \mathrm{ME}$ and $15 \% \mathrm{CP}$

E1P2: $2800 \mathrm{kcal} / \mathrm{kg} \mathrm{ME}$ and $16 \% \mathrm{CP}$

E2P2: $2900 \mathrm{kcal} / \mathrm{kg} \mathrm{ME}$ and $16 \% \mathrm{CP}$

E3P2: $3000 \mathrm{kcal} / \mathrm{kg} \mathrm{ME}$ and $16 \% \mathrm{CP}$

E1P3: $2800 \mathrm{kcal} / \mathrm{kg} \mathrm{ME}$ and $17 \% \mathrm{CP}$

E2P3: $2900 \mathrm{kcal} / \mathrm{kg} \mathrm{ME}$ and $17 \% \mathrm{CP}$

E3P3: $3000 \mathrm{kcal} / \mathrm{kg} \mathrm{ME}$ and $17 \% \mathrm{CP}$

The equivalent of $1 \%$ protein ration is equivalent to $10 \mathrm{~g} / \mathrm{kg}$ protein ration. The treatment rations were given according to according to the required quantity of male ducks needed, which differed in the E/CP balance according to the treatment. Drinking water is given ad libitum. The following presents the nutritional content of the main feed ingredients (Table 1 ) and the treatment rations along with the metabolizable energy (E) and protein (CP) ratios of the given rations arranged according to the E/CP balance of each treatment ration (Table 2).

At the end of the experiment, ducks were fasted from feed for 8-12 hours. To get the slaughter weight, then the duck was decapitated and separated from the blood, feathers, shank, head and internal organs (digestive organs), except for the giblet (gizard, heart, liver) and measured as follows:

\section{Carcass percentage $=$ carcass weight $\times 100 \%$ cutting weight}

While the method for measuring carcass fat, is measured as follows:

Carcass fat percentage $=$ carcass fat weight $\times 100 \%$

\section{carcass weight}

Table 1 - The nutritional composition of feed ingredients used in treatment rations

\begin{tabular}{|c|c|c|c|c|c|c|}
\hline No & Ingredients* & $\begin{array}{c}\text { Protein (CP) } \\
(\%)\end{array}$ & $\begin{array}{c}\text { Energy (ME) } \\
\text { (kcal.kg-1) }^{2}\end{array}$ & $\begin{array}{c}\text { Crude Fiber } \\
\text { (\%) }\end{array}$ & $\begin{array}{l}\mathrm{Ca} \\
(\%)\end{array}$ & $\begin{array}{l}P \\
(\%)\end{array}$ \\
\hline 1. & Fish meal & 39.25 & 2992 & 4.20 & 1.20 & 1.49 \\
\hline 2. & Azolla meal & 21.88 & 2889 & 5.13 & 0.70 & 0.65 \\
\hline 3. & Pollard & 15.50 & 1700 & 8.20 & 0.14 & 0.32 \\
\hline 4. & Yellow corn & 9.12 & 3400 & 3.37 & 0.02 & 0.20 \\
\hline 5. & Rice bran & 10.50 & 1890 & 11.60 & 0.24 & 1.00 \\
\hline 6. & Vegetable oil & 0.00 & 8800 & 0.00 & 0.00 & 0.00 \\
\hline
\end{tabular}


Table 2 - The nutritional content of the treatment and the energy/crude protein balance of the treatment ration

\begin{tabular}{|c|c|c|c|c|c|c|c|c|c|}
\hline Ingredients & E1P1 & E2P1 & E3P1 & E1P2 & E2P2 & E3P2 & E1P3 & E2P3 & E3P3 \\
\hline Fish meal & 9.00 & 9.00 & 10.00 & 11.00 & 11.00 & 12.00 & 19.00 & 19.00 & 21.00 \\
\hline Azolla meal & 27.00 & 25.50 & 19.00 & 35.00 & 35.00 & 29.00 & 15.00 & 18.00 & 13.00 \\
\hline Pollard & 9.00 & 9.00 & 8.50 & 6.00 & 6.00 & 5.00 & 11.00 & 6.00 & 10.00 \\
\hline Yellow corn & 14.00 & 14.00 & 19.50 & 13.00 & 14.00 & 20.00 & 13.00 & 15.00 & 18.00 \\
\hline Rice bran & 36.00 & 36.00 & 36.00 & 31.00 & 29.00 & 29.00 & 36.00 & 36.00 & 31.00 \\
\hline Vegetable oil & 5.00 & 6.50 & 7.00 & 4.00 & 5.00 & 5.00 & 6.00 & 6.00 & 7.00 \\
\hline Total & 100 & 100 & 100 & 100 & 100 & 100 & 100 & 100 & 100 \\
\hline \multicolumn{10}{|c|}{ Composition of nutrient } \\
\hline ME (kcal/kg) & 2800 & 2900 & 3000 & 2800 & 2900 & 3000 & 2800 & 2900 & 3000 \\
\hline $\mathrm{CP}(\%)$ & 15 & 15 & 15 & 16 & 16 & 16 & 17 & 17 & 17 \\
\hline $\mathrm{E} / \mathrm{CP}$ balance & 18.6 & 19.3 & 20.0 & 17.5 & 18.1 & 18.7 & 16.5 & 17.1 & 17.6 \\
\hline
\end{tabular}

\section{Observed variables}

The observed variables were body weight (BW), body weight gain (BWG), feed intake (FI), feed conversion ratio (FCR), carcass percentage, carcass fat, and abdominal fat. The data were analyzed by ANOVA, and if it had a significant effect it was continued with the mean difference test using Duncan's multiple range test (DMRT) according to Steel and Torrie (1993).

\section{RESULTS AND DISCUSSION}

The effect of different energy-crude protein (E/CP) balance supplemented on the growth achievement of Alabio meat ducks is presented in Table 3. Table 3 shows a significant interaction between ration energy (E) and crude protein ration $(p<0.05)$ on the increase in growth performance of male ducks including body weight (BW), body weight gain (BWG), feed intake (FI) and feed conversion ratio (FCR). The E2P3 combination treatment with an E/P balance of $17.05(2900 \mathrm{kcal} / \mathrm{kg}$ $\mathrm{ME}$ and $17 \% \mathrm{CP}$ ) resulted in the highest performance, especially in the most efficient BW, BWG, FI and FCR parameters, while the lowest was the combination of E3P1 treatment with an E/CP balance of 20.0 (3000 kcal/ $\mathrm{kg} \mathrm{ME} \mathrm{and} \mathrm{CP} \mathrm{15 \% ).}$ The response curves for the different E/CP balance effects of all treatments are presented in Figures 1 - 4.

\section{Table 3 - Performance achievement of male Alabio ducks at 6 weeks age with different E/CP rations}

\begin{tabular}{|c|c|c|c|c|c|}
\hline \multirow[b]{2}{*}{ Treatment } & \multirow{2}{*}{$\begin{array}{c}\text { E/CP } \\
\text { balance }\end{array}$} & \multicolumn{4}{|c|}{ Parameter } \\
\hline & & $\begin{array}{c}\text { BW } \\
\text { (g/bird) }\end{array}$ & $\begin{array}{c}\text { BWG } \\
\text { (g/bird) }\end{array}$ & $\begin{array}{c}\text { FI } \\
\text { (g/bird) }\end{array}$ & FCR \\
\hline P1E1 & 18,6 & $964.17 \pm 24.2^{b}$ & $913.17 \pm 26.4^{b}$ & $3198.86 \pm 97.2^{b}$ & $3.50 \pm 0.17 a b$ \\
\hline P1E2 & 19.3 & $928.83 \pm 20.4$ ab & $877.33 \pm 20.3$ ab & $3190.78 \pm 117.1^{b}$ & $3.64 \pm 0.1^{b}$ \\
\hline P1E3 & 20.0 & $813.50 \pm 21.7$ a & $762.50 \pm 20.3 a$ & $2843.70 \pm 97.2^{b}$ & $3.73 \pm 0.15^{b}$ \\
\hline P2E1 & 17.5 & $1083.33 \pm 26.7^{b}$ & $1031.83 \pm 28.8^{b}$ & $3396.44 \pm 125.5^{c}$ & $3.29 \pm 0.24 \mathrm{a}$ \\
\hline P2E2 & 18.1 & $982.33 \pm 21.2^{b}$ & $931.33 \pm 21.4 \mathrm{~b}$ & $3250.04 \pm 103.3 b c$ & $3.49 \pm 0.36 \mathrm{a}$ \\
\hline P2E3 & 18.7 & $932.17 \pm 25.1 \mathrm{ab}$ & $881.17 \pm 21.3$ ab & $3099.69 \pm 105.3 \mathrm{ab}$ & $3.52 \pm 0.07 a b$ \\
\hline P3E1 & 16.5 & $778.83 \pm 18.9$ a & $727.83 \pm 19.2$ a & $3247.86 \pm 132.7 b c$ & $4.46 \pm 0.17^{b}$ \\
\hline P3E2 & 17.1 & $1185.00 \pm 23.5^{d}$ & $1134.00 \pm 27.8^{d}$ & $3563.21 \pm 135.4 d$ & $3.14 \pm 0.09 a$ \\
\hline P3E3 & 17.6 & $1057.00 \pm 24.3^{c}$ & $1005.50 \pm 26.1^{c}$ & $3446.32 \pm 124.6 \mathrm{c}$ & $3.43 \pm 0.19 a$ \\
\hline
\end{tabular}

a,b,c,d. Means in the same column with different letters show significant differences $(p<0.05)$ among dietary treatments. BW: body weight, BWG: body weight gain, Fl: feed intake, FCR: feed conversion ratio 


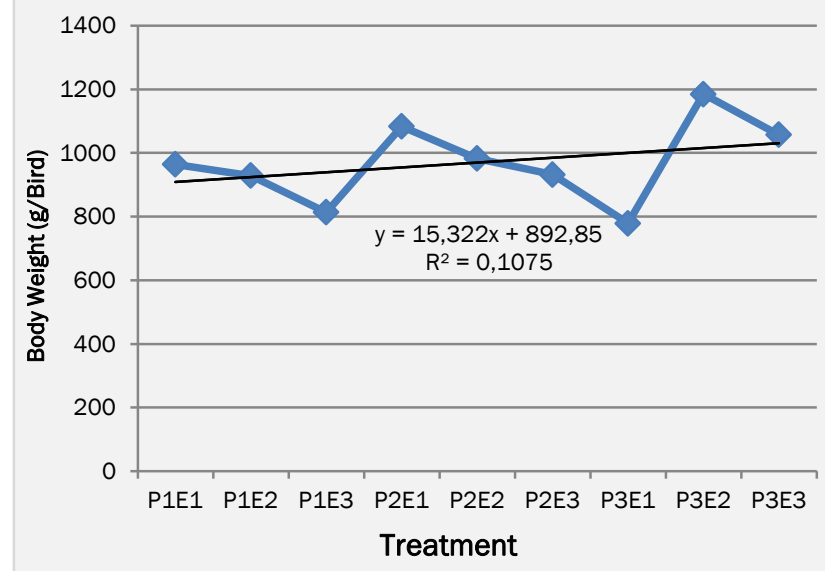

Figure 1- Response curves for the effect of different E/CP balance on Body Weight $(Y)$ with coefficients determination $\left(R^{2}\right)=0.1075$

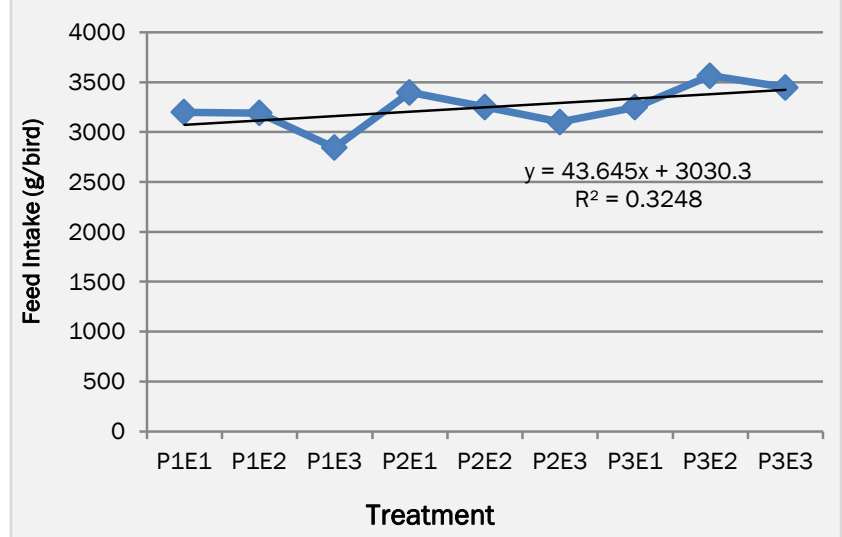

Figure 3 - Response curves for the effect of different E/CP balance on Feed Intake (Y) with coefficients determination $\left(R^{2}\right)=0.3248$

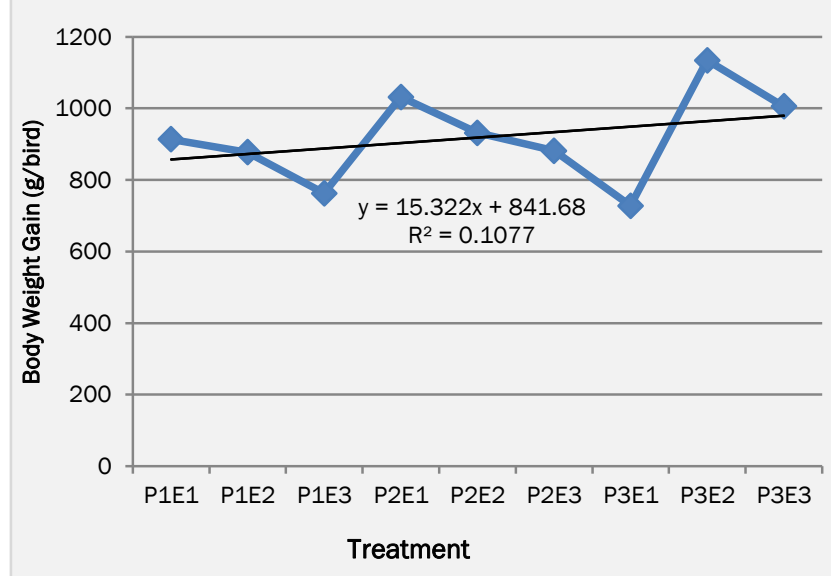

Figure 2 - Response curves for the effect of different E/CP balance on Body Weight determination $\left(R^{2}\right)=0.1077$

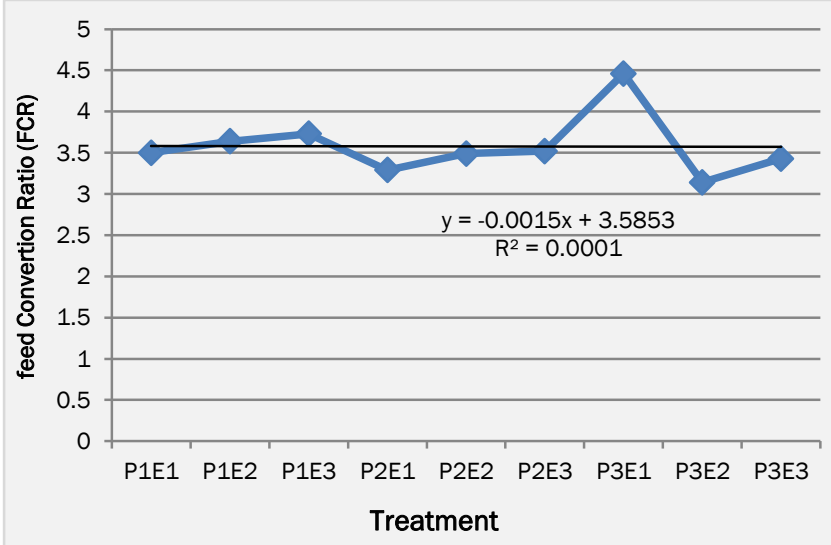

Figure 4 - Response curves for the effect of different E/CP balance on FCR (Y) with coefficients. Determination 0.0001

In the body weight variable (BW), the results of the research on the effect of the best ration E/CP balance were achieved at the E/P ratio of 17.1 produced by the E2P3 treatment $(2900 \mathrm{kcal} / \mathrm{kg} \mathrm{ME}$ and $17 \% \mathrm{CP})$ with a BW achievement of $1185.0 \mathrm{~g} / \mathrm{bird}$. Then in the next order are the treatment of E1P2 and E3P3. This BW result is in line with the body weight gain (BWG) achieved, where the highest result was achieved by the E2P3 treatment of $1134.0 \mathrm{~g} / \mathrm{bird}$ $(p<0.05)$. In Table 3 it can be seen that the highest BW and BWG were produced by rations with an E/CP balance between 17.1 - 17.6, namely E2P3; E1P2 and E3P3 are better than rations with other E/CP ratios in the E/CP balance range of 16.5 - 20.0. The results of this study are in accordance with reports of Tanwiriah (2011; the best ration E/CP balance 17.33 with $2600 / \mathrm{kg}$ energy and $15 \%$ CP for the growth of local male duck), the results of Liu et al. (2019; E/CP balance of 17.6 with $3000 \mathrm{kcal} / \mathrm{kg}$ energy and $17 \%$ CP for pekin ducks), as well as the results obtained by Zeng et al. (2015; at BWG of male ducks with high energy ration of $3285 \mathrm{kcal} / \mathrm{kg} \mathrm{ME} \mathrm{(13.75} \mathrm{MJ/kg)} \mathrm{and} \mathrm{high} \mathrm{protein} \mathrm{(19 \%} \mathrm{CP)} \mathrm{ratio} \mathrm{of} 17.03)$. However, the E/CP balance of the ration in this study was higher than that obtained by Zurmiati et al. (2017) at the E/CP balance of 16.0 (2700 kcal/kg ME, 17\% CP) in Pitalah ducks of $1037.66 \mathrm{~g} / \mathrm{bird}$, and in Cherry Valey ducks reported by Sritiawthai et al. (2013) with an E/CP balance of 15.0 with an energy ration of $2700 \mathrm{kcal} / \mathrm{kg} \mathrm{ME} \mathrm{(11.29} \mathrm{MJ/kg)} \mathrm{and} 18 \%$ CP. The E2P3 ration with an E/CP balance of around 17.1 turned out to be the most suitable E/P balance compared to other E/P ratios for male Alabio ducks that met both energy and protein needs, thus providing optimal BW and BWG growth for ducks. Low energy rations at $2800 \mathrm{kcal} / \mathrm{kg}$ (E1P1, E1P3) resulted in low body weight because these rations had a non-ideal E/CP balance. The low energy content $(2800 \mathrm{kcal} / \mathrm{kg} \mathrm{ME})$ in this study was not able to meet the need to carry out physiological processes in the body of male ducks even though the protein was increased up to 17\% (Tanwiriah, 2011). According to Zeng et al. (2015), this is because if there is a lack of energy, the protein consumed will be converted into energy, the process requires high energy. The increase in the effect of the optimal E/CP balance at the ratio of 17.1 to BW and BWG in this study was also supported by the positive role of giving $2 \%$ phytobiotic herbs in the male duck ration. Biyatmoko et al. (2021) said that giving $2 \%$ phytobiotic herbs from a combination of eight herbs was able to improve the digestibility of the ration which contributed to the growth of poultry compared to controls. The mechanism of action of these phytobiotics through the improvement of the digestibility of food substances which causes an improvement in the digestibility of protein and energy of the ration (Rajput et al., 2013), will lead to an increase in the 
efficiency of the use of nutrients (FCR) and have a positive impact on the growth of ducks (Cheldra et al., 2017; Vinus et al., 2018).

In the feed intake $(\mathrm{FI})$ variable, it can be seen that the interaction of energy factor (E) with protein (CP) showed a significant effect on FI in male Alabio ducks, where the highest FI was achieved by the combination of E2P3 treatment of $3563.21 \mathrm{~g} / \mathrm{bird}$, while the lowest FI was treatment P1E3 with a ratio of E /CP balance 20 (energy $3000 \mathrm{kcal} / \mathrm{kg} \mathrm{ME}$ and $15 \% \mathrm{CP}$ ) with an $\mathrm{FI}$ of $2843.70 \mathrm{~g} / \mathrm{bird}(\mathrm{p}<0.05)$. Higher energy consumption in the treatment E2 $(2900 \mathrm{kcal} / \mathrm{kg} \mathrm{ME})$ and E3 (3000 kcal/ $\mathrm{kg} \mathrm{ME)} \mathrm{was} \mathrm{required} \mathrm{for} \mathrm{high} \mathrm{protein} \mathrm{metabolism.} \mathrm{Energy} \mathrm{consumption} \mathrm{tends} \mathrm{to} \mathrm{be} \mathrm{high} \mathrm{if} \mathrm{protein}$ consumption is high, such as in P2 treatment $(16 \% \mathrm{CP})$ and $\mathrm{P} 3$ treatment $(17 \% \mathrm{CP})$, and if protein consumption is excessive it will be degraded to uric acid which requires high energy (Chen et al., 2016). In addition to high energy consumption, another factor that increased $\mathrm{FI}$ in male Alabio ducks was thought to be due to the addition of $2 \%$ phytobiotic herbs supplementation in the treatment ration which was able to increase saliva production and add better feed flavor (Windisch and Kroismayr, 2007). Although the effect of E/CP treatment was significantly different on FI, but all of them showed an increase in Fl above $3099 \mathrm{~g} /$ bird positive impact of phytobiotic herbs supplementation. As a result of the supplementation of these phytobiotic herbs, there was an increase in saliva levels in the mouth of the poultry so that there was an improvement in the palatability of the ration which triggered a higher appetite (Park et al., 2013). These results are in line with the opinion of Steiner and Syed (2015) that supplementation of phytobiotic herbs is able to stimulate the appetite and consumption of livestock without changing the smell and taste of feed so it is good to be added to animal feed.

In the feed conversion ratio (FCR), the analysis of variance showed a significant effect of interaction of level of energy (E) with protein ration $(C P)(p<0.05)$, where the best effect was also achieved at the $E / C P$ balance of 17.05 in the combination of E2P3 treatment with an FCR value of 3.14. The worst FCR results were produced by the combination of E3P1 treatment with an E/CP balance of 20.0 (3000 kcal/ $\mathrm{kg} \mathrm{ME}$ and 15\% CP) with an FCR value of 3.73 . This result is still within the FCR tolerance for male ducks at the age of six weeks with an FCR range of 2.04 - 4.22 (Saputra et al., 2014). Jamroz et al. (2006) said that one of the indicators to measure the success of increasing growth, one of which is determined by an efficient level of feed consumption and a smaller feed conversion value. However, the determination of a good FCR of male ducks depends on the resulting BWG which can be seen in Table 3 that the treatment that received nutrition with an E/CP balance ranging from 17 (17.1 - 17.6) showed that the average FCR was better in obtaining BW and BWG (E2 and E3) because they are optimally used for growth (Sritiawthai et al., 2013). This is in accordance with the opinion of Wen et al. (2017) imparted that the energy content of the feed determines the feed intake of ducks, and high energy feed will require a higher concentration of amino acids to compensate for the lower feed intake to produce a good FCR of male ducks in Pekin ducks. Wu et al. (2019) said that the optimal feed E/CP balance is very important not only for performance and carcass percentage but also for improving FCR in increasing economic benefits in ducks through duck feed efficiency. On the other hand, supplementation of $2 \%$ phytobiotic herbs helps improve the balance of the duck gut microflora from pathogenic bacteria such as Escericia coli (Dhama et al., 2014), improves the absorption of nutrients in the small intestine (Samarasinghe at al., 2003), as well as a growth promoter growth thereby improving the FCR of ducks (Wiryawan et al., 2005).

The effect of different energy-crude protein (E/CP) balance supplemented on carcass quality of male Alabio ducks is presented in Table 4. Table 4 shows the effect of E/CP balance on carcass percentage, carcass fat and abdominal fat. The results showed that the three variables were significantly influenced by the ratio of the energy-protein balance of the ration $(p<0.05)$. Based on Table 4 it can be seen that the E2P3 treatment with an E/CP balance of $17.05(2900 \mathrm{kcal} / \mathrm{kg}$ $\mathrm{ME}$ and $17 \% \mathrm{CP}$ ) resulted in significantly higher carcass percentage and less carcass fat and abdominal fat content $(p<0.05)$ than all treatments. The response curves for the different E/CP balance effects of all treatments are presented in Figures 5-7.

Table 4 - Carcass quality of male Alabio ducks at 6 weeks age with different E/CP rations

\begin{tabular}{|c|c|c|c|c|}
\hline \multirow{2}{*}{ Treatment } & \multirow{2}{*}{$\begin{array}{c}\mathrm{E} / \mathrm{CP} \\
\text { balance }\end{array}$} & \multicolumn{3}{|c|}{ Parameter } \\
\hline & & Carcass Percentage (\%) & Carcass fat (\%) & Abdominal fat (\%) \\
\hline P1E1 & 18.6 & $64.73 \pm 2.4 a$ & $0.44 \pm 0.02 a$ & $1.09 \pm 0.04 \mathrm{ab}$ \\
\hline P1E2 & 19.3 & $63.78 \pm 2.3 a$ & $0.64 \pm 0.01 \mathrm{ab}$ & $1.37 \pm 0.06^{b}$ \\
\hline P1E3 & 20.0 & $65.25 \pm 2.5 \mathrm{ab}$ & $0.66 \pm 0.03 \mathrm{ab}$ & $1.49 \pm 0.06 b$ \\
\hline P2E1 & 17.5 & $64.58 \pm 2.3 a$ & $0.50 \pm 0.02 \mathrm{a}$ & $0.87 \pm 0.02 \mathrm{a}$ \\
\hline P2E2 & 18,1 & $64.35 \pm 2.2^{a}$ & $0.67 \pm 0.01^{b}$ & $1.17 \pm 0.02 \mathrm{ab}$ \\
\hline P2E3 & 18.7 & $64.68 \pm 2.1^{a}$ & $0.72 \pm 0.01^{c}$ & $1.26 \pm 0.01^{b}$ \\
\hline P3E1 & 16.5 & $62.82 \pm 2.1^{a}$ & $0.56 \pm 0.011^{a}$ & $0.83 \pm 0.03 a$ \\
\hline P3E2 & 17.1 & $67.33 \pm 2.2^{b}$ & $0.37 \pm 0.011^{a}$ & $0.75 \pm 0.03 a$ \\
\hline P3E3 & 17.6 & $64.73 \pm 2.2^{a}$ & $0.45 \pm 0.01^{a}$ & $0.84 \pm 0.02 a$ \\
\hline
\end{tabular}




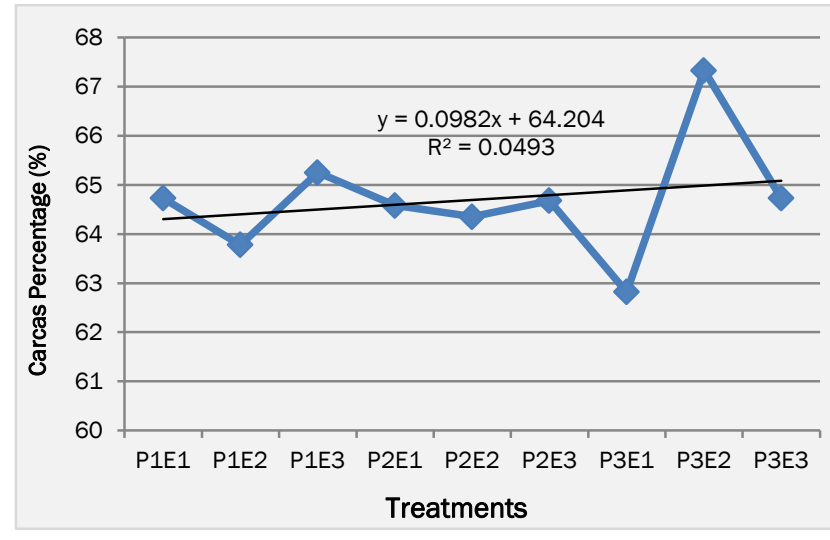

Figure 5 - Response curves for the effect of different E/CP balance on Carcass Percentage $(Y)$ with coefficients determination $\left(R^{2}\right)=0.0493$

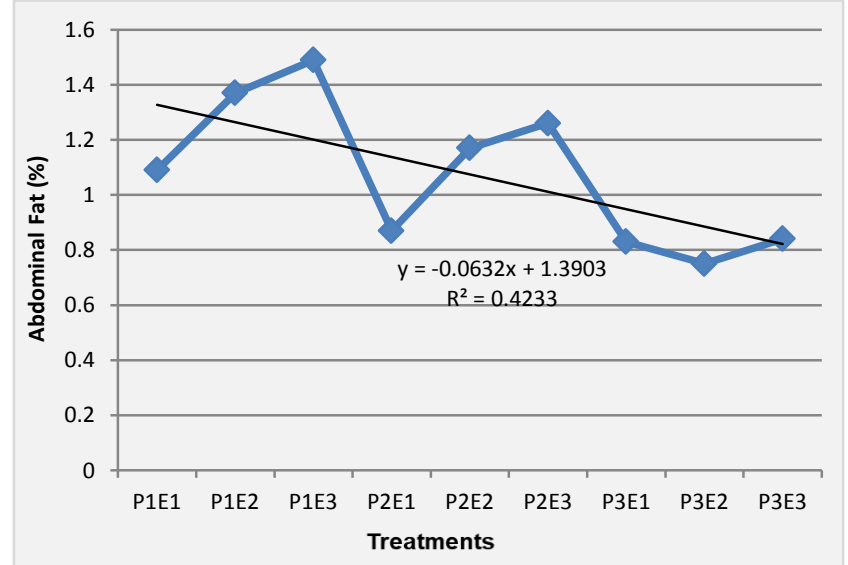

Figure 7 - Response curves for the effect of different E/CP balance on Abdominal Fat $(Y)$ with coefficients determination $\left(R^{2}\right)=0.4233$

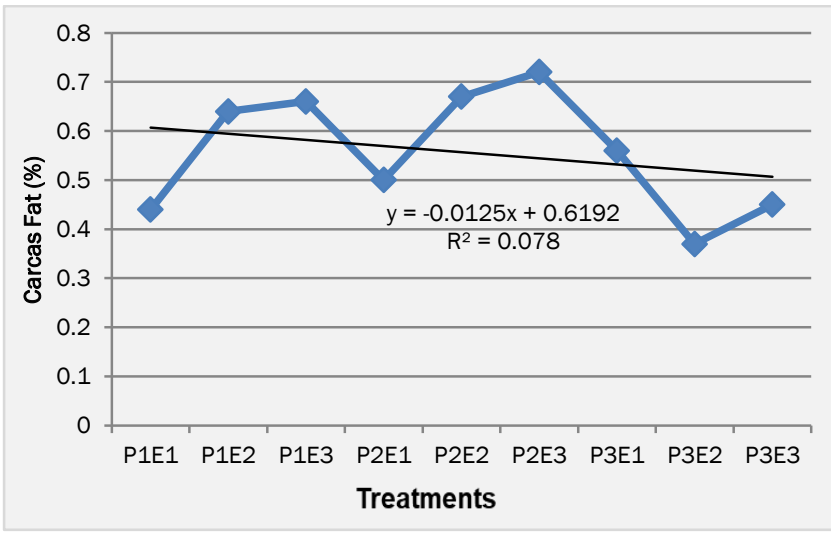

Figure 6 - Response curves for the effect of different E/CP balance on Carcass Fat $(\mathrm{Y})$ with coefficients determination $\left(R^{2}\right)=0.078$

In the male Alabio duck carcass quality variable as shown in Table 4, there was a significant interaction between energy level (E) and protein level (CP) on carcass percentage, carcass fat and abdominal fat $(p<0.05)$. The best interaction on the three variables was produced by a combination of E2P3 treatment with an E/CP balance of $17.1(2900 \mathrm{kcal} / \mathrm{kg}$ $\mathrm{ME}, 17 \% \mathrm{CP}$ ), with the highest carcass percentage achievement of $67.33 \%$, carcass fat and the lowest abdominal fat respectively with the achievement of $0.37 \%$ and $0.75 \%$. Achievements it can be seen that the $\mathrm{E} / \mathrm{CP}$ balance in the range of 17 (E3P3, E1P2, E3P3) is better than the other E/CP ratios, both the E/CP balance of 16; $18 ; 19$ and 20 in this study. For the carcass percentage achievement of $67.33 \%$, this result is higher than the research of Wahyuni et al. (2016) with an E/CP balance of $17(2716 \mathrm{kcal} / \mathrm{kg} \mathrm{ME}, 16.01 \% \mathrm{CP})$ in male Cihateup duck and Rambon ducks were $51.29 \%$ and $51.66 \%$, respectively. Likewise for abdominal fat, this result was lower and better than the results for Cihateup ducks of $0.89 \%$ and Rambon ducks of $0.95 \%$. Based on the results of this study, it was found that the ration with metabolic energy (ME) of $2,900 \mathrm{kcal} / \mathrm{kg}$ and $17 \% \mathrm{CP}$ was in accordance with the needs of male Alabio ducks which produced high carcass, carcass fat and relatively low abdominal fat. The nutrient density of this feed not only has a significant effect on growth performance (BW, BWG, FI, FCR) and input-output ratio (Xie et al., 2017), but also greatly affects the quality of carcass and carcass fat and abdominal fat (Wang et al., 2010; Wen et al., 2017) but the energy density of feed is different according to different production goals (Zeng et al., 2015; Zhao et al., 2017).

\section{CONCLUSION}

The conclusion showed that there was an interaction between ration metabolizable energy (E) and protein ration (CP), where the best results were obtained in the combination of E2P3 treatment with an E/CP balance of $17.1(2,900 \mathrm{kcal} / \mathrm{kg}$ ME with $17 \% \mathrm{CP}$ ), with high performance the best at BW at $1185.0 \mathrm{~g} / \mathrm{bird}$, BWG at $1134.0 \mathrm{~g} / \mathrm{bird}, \mathrm{FI}$ at $3563.21 \mathrm{~g} / \mathrm{bird}$, and FCR at 3.14 and the best carcass quality with the highest carcass percentage reaching $67.33 \%$, and carcass fat and the lowest abdominal fat were $0.37 \%$ and $0.75 \%$, respectively.

\section{DECLARATIONS}

\section{Corresponding author}

Danang Biyatmoko: Email: danangbiyatmoko@ulm.ac.id ; ID Orcid:0000-0002-4377-3105 
Conflict of interest

The authors declare that they have no competing interests.

\section{Author collaboration}

All authors were contributed equally.

\section{Acknowledgements}

We would like to express our gratitude and appreciation to the funders compulsory research lecturer from the University of Lambung Mangkurat.

\section{REFERENCES}

Biyatmoko D (2016). The effect of protease enzyme supplementation to productivity eggs of Alabio duck. International Journal of Biosciences, 8(2): 202-208. Article Link; DOI: http://dx.doi.org/10.12692/ijb/8.2.202-208

Biyatmoko D, Juhairiyah, Prasetio B, Santoso U and Rostini T (2021). The phytobiotic effect of herbs as a growth promoter on the performance and digestibility of Alabio meat ducks. Livestock Research for Rural Development, 33(5): 1-11. Link: https://Irrd.cipav.org.co/Irrd33/5/3362tinti.html

Cheldra AJ, Septinova D, and Kurtini T (2017). Effect of traditional herbal medicine on live weight, carcass weight, giblet weight and broiler abdominal fat. Indonesian Journal of Animal Husbandry Research, 1(2): 16-21. Article Link ; DOI: https://doi.org/10.23960/jrip.2017.1.2.16-21

Chen X, Murdoch R, Zhang Q, Shafer DJ, and Applegate TJ (2016). Effects of dietary protein concentration on performance and nutrient digestibility in Pekin ducks during aflatoxicosis. Poultry Science. 95(4): 834-41. PubMed ; DOI: https://doi.org/10.3382/ps/pev378

Dhama K, Tiwari R, Khan R R, Chakraborti S, Gopi M, Karthik K, Saminathan M, Desingu P A and Sungkara L T (2014). Growth promotor and novel feed additives improving poultry production and health, bioactive principles and beneficial application the trends and advances - a review. International Journal of Pharmacology, 10(3): 129-159. Article Link ; DOI: http://dx.doi.org/10.3923/ijp.2014.129.159

Fan H, Xie M, Wang W, Hou S and Huang W (2008). Effects of dietary energy on growth performance and carcass quality of white growing Pekin ducks from two to six weeks of age. Poultry Science, 87(6): 1162-1164. PubMed ; DOI: https://doi.org/10.3382/ps.2007-00460

Jamroz D, Wertelecki T, Houszka M and Kamel C (2006). Influence of diet type on the inclusion of plant origin active substances on morphological and histochemical characteristics of the stomach and jejunum walls in chicken. Journal of Animal Physiology and Animal Nutrition, 90(5-6): 255-268. PubMed ; DOI: https://doi.org/10.1111/i.1439-0396.2005.00603.x

Liu JB, Yan HL, Zhang Y, Hu YD and Zhang HF (2019). Effects of dietary energy and protein content and lipid source on growth performance and carcass traits in Pekin ducks. Poultry Science, 98(10): 4829 - 4837. Article Link ; DOI: https://doi.org/10.3382/ps/pez217

Murawska D (2012). The effect of age on the growth rate of tissues and organs and the percentage content of edible and nonedible carcass components in Pekin ducks. Poultry Science, 91(8): 2030-2038. Article Link ; DOI: https://doi.org/10.3382/ps.2011-02083

Niu ZY, Shi J, Liu F, Wang X, Gao C. and Yao L (2009). Effects of dietary energy and protein on growth performance and carcass quality of broilers during starter phase. International Journal of Poultry Science, 8(5): 505-511. Article Link ; DOI: https://dx.doi.org/10.3923/ijps.2009.508.511

Park S 0, Ryu C M, Park B S and Hwangbo J (2013). The meat quality and growth performance in broiler chickens feed diet with cinnamon powder. Journal of Environmental Biology, 34(1): 127-133. https://pubmed.ncbi.nlm.nih.gov/24006819/

Rajput N, Muhammah M, Yan R, Zhong X and Wang T (2013) Effect of dietary supplementation of curcumin on growth performance, intestinal morphology and nutrients utilization of broiler chicks. Journal of Poultry Science, 50(1): 44-52. Article Link ; DOI: https://doi.org/10.2141/jpsa.0120065

Rostini T, Biyatmoko D and Wahdi A (2021). Productivity of laying alabio duck and its eggs quality under exposure of different intensity and color of led light. Tropical Animal Science Journal, 44(2): 205-212. Article Link ; DOI https://doi.org/10.5398/tasj.2021.44.2.205

Samarasinghe K, Wenk C, Silva KFST and Gunasekera JMDM (2003). Turmeric (curcuma longa) root powder and mannanoligosaccharides as alternatives to antibiotics in broiler chicken diets. Asian-Australasian Journal of Animal Sciences, 16(10): 1495-1500. Article Link ; DOI: https://doi.org/10.5713/ajas.2003.1495

Saputra DH, Dani G dan Adriani L (2014). Effect of limiting the level of protein in the ration on edible and in edible on local male ducks. Journal of the Faculty of Animal Husbandry, University of Padjadjaran: Jatinangor-Sumedang, 3(1): 4-5. Link: https://jurnal.unpad.ac.id/ejournal/article/view/3596

Sritiawthai E, Sakuthai S, Sakdee J, Bunchasak C, Kaewtapee C and Poeikhampa T (2013). Effect of protein level and dietary energy on production, intestinal morphology and carcass yield of meat duck during starter phase of 14 days. Journal of Applied Science 13(2): 315 - 320. Article Link ; DOI: https://dx.doi.org/10.3923/jas.2013.315.320

Steel RGD and Torrie JH (1993). Principles And Procedures of Statistics : A biometric approach. Bambang Sumantri's translation. Gramedia Pustaka Utama, Jakarta. Link: https://onesearch.id/Record/IOS3774.JAKPU000000000005505

Steiner T and Syed SBA (2015). Phytogenic feed additives in animal nutrition. medicinal and aromatic plants of the world, Springer, Dordrecht. pp. 403-423. DOI: https://doi.org/10.1007/978-94-017-9810-5_20 
Suryana, Kurniawan H, and Hadi SN (2016). Carcass quality of broiler ducks with different dose levels of herbal medicine. Proceedings of the National Seminar on Agricultural Technology Innovation, Banjabaru, July 20, 2016, pp. 141-151. Link: http://kalsel.litbang.pertanian.go.id/ind/images/pdf/Semnas2016/14_suryana.pdf

Tanwiriah W (2011). Performance of male Muscovy ducks (Cairina moschata) at various energy/protein rations under different housting system. Indonesian Journal of Applied Sciences, 1(1): 40-50. Available at: http://jurnal.unpad.ac.id/ijas/article/view/1847

Vinus, Rajesh D, Nancy S, Maan NS and Tewatia BS (2018). Potential benefits of herbs supplements in poultry feed: A review. The Pharma Innovation Journal, 7: 651-656. Link: https://www.thepharmajournal.com/archives/2018/vol7issue6/PartJ/76-119-805.pdf

Wahyuni HS, Abun and Sudjana E (2016). Response of Cihateup Ducks and Male Rambon Ducks to Energy-Protein Ration Balance in a Water-Minim Maintenance System. Journal of Animal Science, 16(2):1-9. Article Link ; DOI: https://doi.org/10.24198/jit.v16i2.11569

Wang, Q, Li HF, Dai YL, Chen KW, Li BL, Wang ZY and Zhang J (2010). Effect of dietary crude protein and energy on gaoyou ducklings growth performance and carcass trait. Journal of Animal and Veterinary Advances, 9(4):826-830. Article Link ; DOI: $10.3923 /$ javaa.2010.826.830

Wen ZG, Rasolofomanana TJ, Tang J, Jiang Y, Xie M, Yang PL, and Hou SS (2017). Effects of dietary energy and lysine levels on growth performance and carcass yields of Pekin ducks from hatch to 21 days of age. Poultry Science, 96(9): 3361 - 3366. PubMed ; DOI: https://doi.org/10.3382/ps/pex122

Windisch W and Kroismary A (2007). The effect of phytobiotics on performance and gut function in monogastrics. University of Natural Resources and Applied Life Sciences Vienna. Ergomix Press. Link: https://en.engormix.com/feedmachinery/articles/phytobiotics-on-performance-gut-function-in-monogastrics-t33528.htm

Wiryawan K G, Suharti S, Bintang M (2005). Antibacterial study of temulawak, ginger and garlic against salmonella typhimurium and the effect of garlic on performance and immune response of broilers. Animal Husbandry Media, 28: 52 - 62. Link: https://journal.ipb.ac.id/index.php/mediapeternakan/article/view/762

Wu Y, Liu J, Shahid MS, Xiao Z, Dong X, Yin D and Yuan J (2019). Effects of dietary energy and protein levels on free force-feed Peking Ducks. Journal of Applied Poultry Research, 28(3): 606-615. Article Link ; DOI: https://doi.org/10.3382/japr/pfz011

Xie M, Jiang Y, Tang J, Zhang Q, Huang W, and Hou SS (2017). Starter and subsequent grower response of Pekin ducks to lowprotein diets in starter phase. Livestock Science, 203: 92-96. Article Link ; DOI: https://doi.org/10.1016/j.livsci.2017.07.005

Zeng QF, Cherry P, Doster A, Murdoch R, Adeola 0 and Applegate TJ (2015). Effect of dietary energy and protein content on growth and carcass traits of Pekin ducks. Poultry Science, 94(3): 384-394. DOI: https://dx.doi.org/10.3382\%2Fps\%2Fpeu069

Zhao PY and Kim IH (2017). Effect of diets with different energy and lysophospholipids levels on performance, nutrient metabolism, and body composition in broilers. Poultry Science, 96(5): 1341-1347. Article Link ; DOI: https://doi.org/10.3382/ps/pew469

Zurmiati, Wizna H. Abbas, Mahata ME and Fauzano R (2017). Effect of Bacillus amyloliquefaciensas a probiotic on growth performance parameters of Pitalah ducks. International Journal of Poultry Science, 16(4): 147-153. Article Link ; DOI: https://dx.doi.org/10.3923/ijps.2017.147.153 